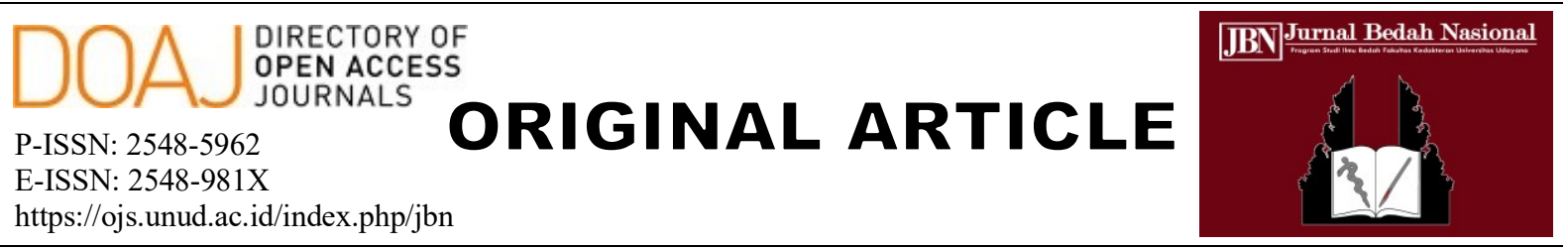

https://ojs.unud.ac.id/index.php/jbn

\title{
Pengaruh Aktivitas Fisik Walking Exercise Program (WEP) terhadap Cancer Related Fatigue (CRF) pada Pasien Kanker Payudara di RSUP Sanglah
}

\section{Gede Sukma Pranata Darma ${ }^{1}$ I Gede Budhi Setiawan ${ }^{2}$, I Gde Raka Widiana ${ }^{3}$}

${ }^{1}$ Residen Bedah Umum, Fakultas Kedokteran Universitas Udayana, Rumah Sakit Umum Pusat Sanglah, Denpasar, Bali, Indonesia.

${ }^{2}$ Divisi Bedah Onkologi, Departemen Ilmu Bedah, Fakultas Kedokteran Universitas Udayana, Rumah Sakit Umum Pusat Sanglah, Denpasar, Bali, Indonesia.

${ }^{3}$ Divisi Nefrologi, Departemen Ilmu Penyakit Dalam, Fakultas Kedokteran Universitas Udayana, Rumah Sakit Umum Pusat Sanglah, Denpasar, Bali, Indonesia.

*Penulis korespondensi: gedesukmap@gmail.com.

\section{ABSTRAK}

Tujuan: Untuk mengetahui pengaruh antara walking exercise programme (WEP) terhadap cancer related fatigue (CRF) pada pasien kanker payudara di RSUP Sanglah Denpasar. Metode: Penelitian randomized controlled trial group pretest-posttest design ini dilakukan pada seluruh pasien kanker payudara yang dirawat di RSUP Sanglah Denpasar pada tahun 2018, untuk dibedakan dalam kelompok kontrol dan kelompok perlakuan (yang menjalani WEP). Pengambil data dan pengolah data disamarkan mengenai kondisi randomisasi dan perlakuan. WEP dilaksanakan selama tiga minggu yang dilakukan sebanyak 3 kali dalam seminggu selama 30 menit. Pada kedua kelompok dilakukan penilaian skor brief fatigue inventory (BFI) sebelum dan sesudah perlakuan. Data kemudian dikumpulkan dan dilakukan analisis statistik dengan SPSS 25.0. Hasil: Penelitian awalnya terdiri dari 41 peserta di kelompok intervensi dan 41 di kelompok kontrol. Dua peserta dari kelompok kontrol mengundurkan diri dari penelitian. Pada analisis skor BFI setelah latihan, ditemukan bahwa skor BFI pada kelompok intervensi menurun secara signifikan dibandingkan kelompok kontrol $(2,8 \pm 1,2 v s$. $0,2 \pm 0,7 ; \mathrm{p}<0,001)$. Dengan uji multivariat ANCOVA ditemukan bahwa setelah mengendalikan variabel perancu, aktivitas fisik WEP tetap dapat memberikan efek 2,5 kali lebih besar dibanding kontrol $(p=0,001)$. Simpulan: Aktivitas fisik WEP menurunkan tingkat CRF pada pasien kanker payurada 2,5 lebih besar jika dibandingkan dengan kontrol sehingga direkomendasikan sebagai salah satu penanganan CRF pada pasien dengan kanker payudara.

Kata kunci: walking exercise program, WEP, fatigue, cancer related fatigue, CRF.

DOI: https://doi.org/10.24843/JBN.2021.v05.i01.p02

\begin{abstract}
Aim: To determine the influence of walking exercise programme (WEP) on cancer related fatigue (CRF) in breast cancer patients. Methods: This study is a randomized controlled trial group pretestposttest design experimental study, conducted on all breast cancer patients admitted to Sanglah Denpasar Hospital in 2018, who are 18-60 years old. Data takers and data processing are camouflaged for randomization and intervention. In the control group, no exercise was done. In the intervention group, WEP was carried out for three weeks which is done 3 times a week for 30 minutes. Brief fatigue inventory (BFI) scores were assessed before and after treatment. The data was then analyzed with SPSS 25.0. Results: The study initially consisted of 41 subjects in the control and intervention group, respectively. Two subjects from the control group withdrew from the study. This study showed that BFI scores in the intervention group decreased significantly compared to the control group $(2.8 \pm 1.2$ vs. $0.2 \pm 0.7 ; \mathrm{p}<0.001)$. From ANCOVA multivariate statistical analysis, it was showed that WEP physical activity had 2.5 times greater than control $(p=0.001)$ on reducing CRF after confounding factors controlled. Conclusion: The walking exercise programme decreased CRF levels
\end{abstract}


in breast cancer patients 2.5 greater when compared to controls, thus the programme was recommended as one of CRF prevention in patients with breast cancer.

Keywords: walking exercise program, WEP, fatigue, cancer related fatigue, CRF.

\section{PENDAHULUAN}

Kanker payudara merupakan salah satu jenis kanker paling mematikan, khususnya bagi wanita. Cancer related fatigue (CRF) adalah salah satu gejala yang paling sering dialami oleh pasien kanker, termasuk pasien kanker payudara, yang merupakan akibat dari kanker itu sendiri atau sebagai efek samping dari pengobatan kanker. ${ }^{1}$ Penelitian klinis multisenter menunjukkan bahwa insiden CRF berkisar antara 70\%-80\% pada pasien kanker payudara. ${ }^{2}$ CRF pada beberapa penelitian ditunjukkan tidak berkurang setelah pengobatan dimana $15 \%$ sampai $50 \%$ pasien kanker payudara dilaporkan tetap mengalami fatigue setelah pengobatan. ${ }^{3}$ Dalam sebuah studi terbaru yang melibatkan 763 wanita yang telah sembuh dari kanker payudara, ditemukan bahwa 35\% masih mengalami CRF dalam 1-5 tahun setelah selesai pengobatan, dan 34\% dilaporkan masih mengalami CRF dalam 5-10 tahun setelah selesai pengobatan. ${ }^{4}$

Beberapa studi telah menunjukkan bahwa latihan fisik memiliki efek positif pada kualitas hidup dan kebugaran, sehingga meningkatkan angka harapan hidup. ${ }^{5}$ The American College of Sports Medicine (ACSM) merekomendasikan aktivitas fisik berupa program latihan berjalan / walking exercise program (WEP) yang tergolong aman pada penderita kanker. ${ }^{6}$ Dalam studi meta analisis, latihan fisik menunjukkan perbaikan dari CRF dengan effect size yang besar. ${ }^{7}$ Menurut Patel, latihan fisik di rumah tanpa pengawasan selama kemoterapi andjuvan tidak mengurangi tingkat CRF pada pasien kanker payudara. ${ }^{8}$
Perbedaan hasil penelitian bisa terjadi karena perbedaan metode penelitian dan populasi yang diteliti. Di Bali, belum ada penelitian yang sama. Berdasarkan hal tersebut di atas, maka sangat penting untuk mengetahui hubungan antara aktivitas fisik berupa WEP dan CRF pada pasien kanker payudara di RSUP Sanglah Denpasar. Dengan mengetahui hal ini, dapat direkomendasikan apakah aktivitas fisik tersebut dapat diaplikasikan pada pasien di di RSUP Sanglah. Hal ini diharapkan memiliki dampak untuk meningkatkan fungsi fisik dan spiritual serta kemampuan dalam melakukan aktivitas sehari-hari sehingga kualitas hidup pasien-pasien yang menderita kanker dapat terus meningkat.

\section{METODE}

Penelitian ini merupakan penelitian eksperimental dengan pendekatan open label randomized controlled trial group pretestposttest design. Penelitian ini telah mendapat persetujuan dari komite etik. Seluruh pasien kanker payudara yang dirawat di RSUP Sanglah Denpasar pada tahun 2018 yang berusia 18-60 tahun dan menyetujui informed consent dimasukkan dalam penelitian ini. Pasien kanker payudara yang tidak mampu melakukan WEP karena disabilitas dan tidak mampu melakukan WEP karena skor Karnofksy yang buruk menjadi kriteria eksklusi.

Penelitian ini bertujuan menilai CRF (variabel dependen) pada kelompok yang melakukan dan tidak melakukan WEP (variabel independen). WEP yang merupakan program olahraga yang dikembangkan berdasarkan prinsip-prinsip frekuensi, durasi, 
intensitas, dan aktifitas yang disarankan oleh ACSM. WEP dilaksanakan selama tiga minggu yang dilakukan sebanyak 3 kali dalam seminggu selama 30 menit dengan kecepatan 0,5-1 meter/detik dalam 3 hari setiap minggu pada hari ke-1, ke-3 dan ke-5 dan dilakukan selama 3 minggu. Pasien diarahkan untuk berjalan santai selama 30 menit dengan kecepatan 0,5-1 meter/detik. Jika pasien menjalani waktu berjalan kurang dari 80\% (216 menit) dari total seluruh waktu latihan makan pasien akan dinyatakan gugur dan tidak diikutkan dalam analisis data. Pada kelompok kontrol tidak diberikan program latihan WEP namun dilakukan edukasi untuk tetap beraktivitas seperti biasa yang dilakukan setiap harinya.

CRF dihitung dengan menggunakan brief fatigue inventory (BFI) yang merupakan kuesioner yang dikembangkan dan disusun untuk menilai tingkat fatigue pada pasien kanker. Skala CRF dihitung berdasarkan ratarata skor dari sembilan poin yang di evaluasi (tiga poin untuk mengevaluasi intensitas kelelahan dan enam poin untuk mengevaluasi pengaruh kelelahan terhadap aktivitas seharihari.

Pada seluruh subjek yang ikut serta dalam penelitian, dilakukan randomisasi dengan bantuan program komputer, untuk menentukan kelompok kontrol (yang tidak menjalani intervensi WEP) dan kelompok perlakuan (yang menjalani intervensi WEP). Pengambil data dan pengolah data disamarkan mengenai kondisi randomisasi dan perlakuan. Pada kedua kelompok dilakukan pretest dan posttest dengan menggunakan BFI untuk menilai skala fatigue yang dialami. Selain itu, juga dilakukan pencatatan tekanan darah dan frekuensi nadi sebelum dan setelah berjalan. Diakhir minggu ketiga kedua kelompok akan dilakukan posttest dengan menggunakan BFI untuk menilai skala fatigue setelah 3 minggu.
Data kemudian dikumpulkan dan dilakukan analisis statistik dengan SPSS 25.0. Secara deskriptif, akan diperoleh gambaran data, sebaran data secara lebih terperinci. Analisis perbedaan tingkat CRF dilakukan dengan uji beda rerata yaitu uji t-independen jika data terdistribusi nomal dan uji MannWhitney jika data tidak terdistribusi normal. Di sisi lain, uji multivariat ANCOVA digunakan utuk melihat pengaruh WEP terhadap CRF dengan memperhitungkan variable perancu pada karakteristik data. Tingkat kemaknaan ditetapkan berdasarkan pada nilai $\mathrm{p}<0,05$.

\section{HASIL}

Penelitian awalnya terdiri dari 41 peserta di kelompok intervensi dan 41 di kelompok kontrol. Dua peserta dari kelompok kontrol mengundurkan diri dari penelitian. Pada penelitian ini didapatkan pada kelompok intervensi usia 46,4 $\pm 8,1$ tahun. Pada kelompok intervensi peserta lebih banyak dengan stadium II sebanyak 21 peserta (51,2\%) (Tabel 1).

Rerata skor BFI pada kelompok intervensi dan kelompok kontrol tidak berbeda secara signifikan $(p=0,063)$. Pada analisis skor BFI setelah latihan, ditemukan bahwa skor BFI pada kelompok intervensi menurun secara signifikan dibandingkan kelompok kontrol $(2,8 \pm 1,2$ vs. $0,2 \pm 0,7)$. Dari hasil analisis statistik dengan uji t-independen, ditemukan perbedaan penurunan skor BFI yang menginterpretasikan CRF secara signifikan antara kelompok yang menjalani intervensi WEP dibandingkan kelompok kontrol $(p<0,001$; Tabel 2).

Dari Gambar 1, dapat dilihat gradient penurunan CRF pada kelompok intervensi lebih curam dibandingkan pada kelompok kontrol. 
Tabel 1. Karakteristik Subjek Penelitian bedasarkan Kelompok Intervensi dan Kontrol

\begin{tabular}{lccc}
\hline \multirow{2}{*}{ Variabel } & \multicolumn{2}{c}{ Kelompok } & \multirow{2}{*}{ Nilai p } \\
\cline { 2 - 3 } & Intervensi (n=41) & Kontrol (n=39) & \multirow{2}{*}{0,119} \\
Umur, tahun (mean \pm SD) & $46,4 \pm 8,1$ & $49,1 \pm 7,2$ & \\
Stadium peyakit (\%) & & & \\
$\quad$ I & $2(4,9)$ & $0(0,0)$ & 0,008 \\
II & $17(51,2)$ & $13(33,3)$ & \\
III & $1(2,4)$ & $20(51,3)$ & \\
IV & $1(2,4)$ & $6(15,4)$ & \\
Status gizi (\%) & $32(78,0)$ & $2(5,1)$ & \\
$\quad$ Kurang & $8(19,5)$ & $25(64,1)$ & \\
$\quad$ Normal & & $12(30,8)$ & \\
$\quad$ Lebih & $8(19,5)$ & & \\
Riwayat penyakit kronis $(\%)$ & $33(80,5)$ & $6(15,4)$ & 0,627 \\
$\quad$ Ya & $1(2,4)$ & $33(84,6)$ & \\
$\quad$ Tidak & $18(43,9)$ & & \\
Terapi saat ini (\%) & $15(36,6)$ & $33(84,6)$ & \\
$\quad$ Operasi & $1(2,4)$ & $2(5,1)$ & 0,040 \\
$\quad$ Kemoterapi & $6(14,6)$ & $0(0)$ & \\
$\quad$ Hormonal terapi & $100 \pm 10$ & $4(10,3)$ & \\
$\quad$ Radiasi & & $100 \pm 10$ & 0,061 \\
$\quad$ Selesai terapi & & \\
Skor Karnofsky (Median $\pm \mathrm{IQR})$ & & & \\
\hline
\end{tabular}

SD: standar deviasi, IQR: interquartile range

Tabel 2. Perbandingan Tingkat CRF Sebelum Aktifitas Fisik WEP, Sesudah Aktifitas Fisik WEP dan Penurunan CRF Berdasarkan Kelompok Intervensi dan Kontrol

\begin{tabular}{|c|c|c|c|}
\hline \multirow[t]{2}{*}{ Variabel } & \multicolumn{2}{|c|}{ Kelompok } & \multirow[t]{2}{*}{ Nilai $p$} \\
\hline & Intervensi $(n=41)$ & Kontrol $(n=39)$ & \\
\hline $\begin{array}{l}\text { Kelelahan sebelum latihan (Skor BFI), } \\
\text { Rerata } \pm \text { SD }\end{array}$ & $4,2 \pm 1,1$ & $3,8 \pm 0,9$ & 0,063 \\
\hline $\begin{array}{l}\text { Kelelahan setelah latihan (Skor BFI), } \\
\text { Median (IQR) }\end{array}$ & $1,1(0,8)$ & $3,3(1,2)$ & $<0,001$ \\
\hline $\begin{array}{c}\text { Penurunan kelelahan } \\
\text { Median (IQR) }\end{array}$ (Skor BFI), & $2,8(1,2)$ & $0,2(0,7)$ & $<0,001$ \\
\hline
\end{tabular}

SD: standar deviasi, IQR: interquartile range

Tabel 3 Hasil Uji ANCOVA Pengaruh Aktivitas Fisik WEP Terhadap Penurunan CRF Setelah Mengendalikan Variabel Perancu

\begin{tabular}{lccc}
\hline \multicolumn{1}{c}{ Variabel } & B & $\mathbf{9 5 \%}$ CI & Nilai $\boldsymbol{p}$ \\
\hline Intervensi & 2,5 & $2,039-3,041$ & $<0,001$ \\
Umur & $-0,003$ & $-0,034-0,029$ & 0,865 \\
Stadium & 0,109 & $-0,247-0,465$ & 0,554 \\
Status gizi & $-0,169$ & $-0,638-0,300$ & 0,476 \\
Riwayat terapi saat ini & $-0,112$ & $-0.351-0.126$ & 0,351 \\
\hline
\end{tabular}




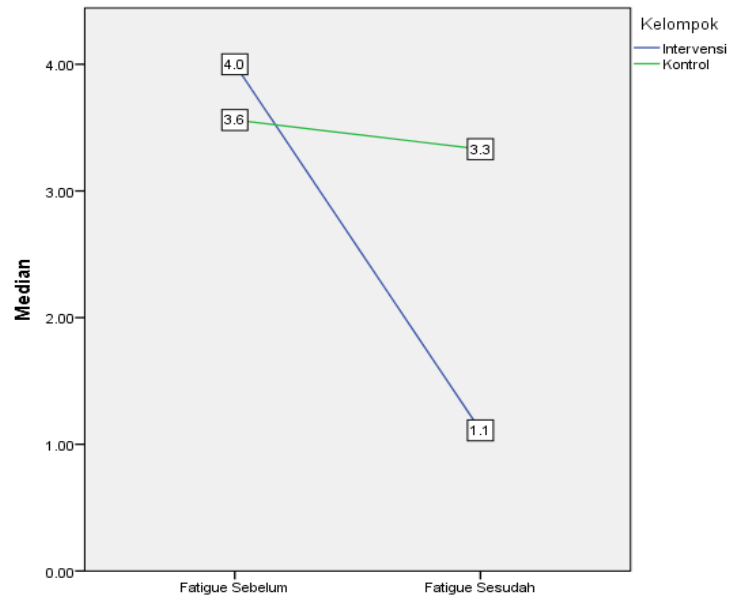

Gambar 1. Grafik CRF sebelum dan sesudah latihan pada kelompok intervensi dan kontrol

Pada uji statistik ANCOVA untuk mengetahui pengaruh aktivitas fisik WEP terhadap penurunan CRF dengan mengendalikan variabel perancu seperti umur, stadium penyakit, status gizi, skor Karnofsky, ditemukan bahwa aktivitas fisik WEP dapat memberikan efek 2,5 kali lebih besar dibanding kontrol (95\%CI 2,039-3,041; $\mathrm{p}=0,001$; Tabel 3).

\section{DISKUSI}

Kelelahan (fatigue) merupakan salah satu keluhan yang sering dialami oleh orang dengan kanker. CRF didefinisikan sebagai perasaan kelelahan (fatigue) yang bersifat subjektif, menetap dan mengganggu aktifitas sehari-hari yang merupakan gejala dari kanker itu sendiri atau efek samping dari terapi kanker. Karakteristik khas dari CRF ditandai dengan perasaan kelelahan, lemah, dan kekurangan energi yang tidak dapat hilang dengan istirahat atau tidur. ${ }^{3}$ Tingkat CRF yang dirasakan dihitung dengan menggunakan brief fatigue inventory (BFI) yang merupakan kuesioner yang dikembangkan dan disusun untuk menilai tingkat fatigue pada pasien kanker. ${ }^{5}$

Patofisiologi dari CRF belum diketahui secara pasti. Dipercaya bahwa disregulasi sitokin memiliki peran penting terjadinya
CRF. Meningkatnya biomarker inflamasi seperti interleukin-6 (IL-6) dan tumor necrosis factor-alpha (TNF- $\alpha$ ) didapatkan pada studi tentang kelelahan di pasien kanker. ${ }^{9}$ Dalam studi oleh Rich dikatakan bahwa ligan epidermal growth factor receptor (EGFR) seperti transforming growth factor-alpha (TGF- $\alpha$ ) menghambat sinyal hipotalamic ritmic behaviour yang berakibat kelelahan, gangguan siklus sirkardian dan kehilangan napsu makan. ${ }^{10}$

Aktifitas fisik seperti WEP menjadi salah satu pilihan terapi untuk mengurangi tingkat CRF. WEP direkomendasikan oleh ACSM sebagai pilihan latihan karena dapat meningkatkan kekuatan tubuh, daya tahan tubuh dan fungsi kekebalan tubuh. ${ }^{11}$ Selain itu aktifitas fisik rutin seperti WEP juga memililiki efek menurunkan stres emosional dan kecemasan yang sering dialami pasien dengan kanker. ${ }^{12}$

Penelitian ini menunjukkan bahwa aktivitas WEP secara signfikan menurunkan CRF yang direpresentasikan oleh skor BFI dibandingkan populasi yang tidak melakukan aktivitas $(p<0,001)$. Uji statistik selanjunya untuk kontrol variabel perancu tetap mempertahankan efek signifikan WEP, di mana ditunjukkan WEP dapat memberikan efek 2,5 kali lebih besar dibanding kontrol (CI 2,039-3,041, $\mathrm{p}=0,001$ ). Hasil penelitian ini sejalan dengan penelitian sebelumnya dimana ditunjukkan aktivitas fisik berjalan dapat menurunkan tingkat CRF secara signifikan ${ }^{11,13}$, meningkatkan kualitas hidup $^{14}$, dan memperbaiki CRF pada pasien yang menjalani kemoterapi dan radioterapi. ${ }^{8,15}$ Akan tetapi, tidak dianjurkan latihan fisik tanpa supervisi di mana meta analisis Velthus dkk. menunjukkan bahwa latihan fisik tanpa supervisi di rumah memberian efek yang kecil sampai tidak ada terhadap penurunan CRF (mean 0,10 dengan CI 95\% -0,25-0,45). ${ }^{16}$ Pada latihan fisik yang 
dilakukan sendiri tanpa supervisi memungkinkan tidak terpenuhinya tujuan latihan yang diinginkan berupa jenis, intensitas dan durasi latihan sehingga efek pada fatigue tidak bermakna.

Aktivitas fisik yang disarankan untuk orang dengan kanker payudara berupa aktivitas latihan dengan intensitas sedang dan teratur. ${ }^{6}$ Disaat seseorang beraktivitas fisik olahraga tubuh akan meregulasi kembali sitokin dengan menekan kadar IL-6 dan TNF$\alpha$ dan memproduksi antiinflamasi IL-1 ra (receptor antagonis) dan IL-10. Selain itu, pada tubuh pasien yang melakukan aktivitas fisik akan terjadi penekanan terhadap sitokin proinflamasi TNF- $\alpha$. Menurut Ahmad $\mathrm{H}$, latihan fisik rutin selama 4 minggu secara signifikan meningkatkan kadar kortisol dalam darah yang mengakibatkan menurunnya tingkat kelelahan. ${ }^{17}$ Oleh karena itu, WEP merupakan salah satu jenis latihan yang disarankan ACSM karena memiliki komponen penting seperti frekuensi, intensitas, waktu, dan kemajuan yang sesuai untuk pasien dengan kanker. ${ }^{4,11}$

\section{SIMPULAN}

Aktivitas fisik WEP menurunkan tingkat CRF pada pasien kanker payudara 2,5 lebih besar jika dibandingkan dengan kontrol sehingga direkomendasikan sebagai salah satu penanganan CRF pada pasien dengan kanker payudara.

\section{UCAPAN TERIMA KASIH}

Penulis mengucapkan terima kasih kepada berbagai pihak yang telah membantu selama pelaksanaan penelitian dan penyusunan artikel publikasi.

\section{PERNYATAAN}

Penulis menyatakan tidak ada konflik kepentingan dalam laporan ini.

\section{DAFTAR PUSTAKA}

1. Fabi A, Bhargava R, Fatigoni S, dkk. Cancer-related fatigue: ESMO Clinical Practice Guidelines for diagnosis and treatment. Ann Oncol. 2020;31:713-23.

2. Lawrence DP, Kupelnick B, Miller K. Evidence report on the occurrence, assessment, and treatment of fatigue in cancer patients. $J$ Natl Cancer Inst Monogr. 2004;32:40-50.

3. Curt GA, Breitbart W, Cella D, dkk. Impact of cancer-related fatigue on the lives of patients: new findings from the fatigue coalition. Oncologist. 2000;5:35360.

4. Bower JE, Ganz PA, Desmond KA, dkk. Fatigue in long-term breast carcinoma survivors: a longitudinal investigation. Cancer. 2006;106:751-8.

5. Szymlek-Gay EA, Richards R, Egan R. Physical activity among cancer survivors: a literature review. $N Z$ Med $J$. 2011;124:77-89.

6. World Health Organization. Global recommendation on physical activity for health. Switzerland: WHO Library Cataloguing-in-Publication Data; 2010.

7. Pinto BM, Frierson GM, Rabin C, dkk. Home-based physical activity intervention for breast cancer patients. $J$ Clin Oncol. 2005;23:3577-87.

8. Patel JG, Bhise AR. Effect of Aerobic Exercise on Cancer-related Fatigue. Indian J Palliat Care. 2017;23:355-61.

9. Collado-Hidalgo A, Bower JE, Ganz PA, dkk. Inflammatory biomarkers for persistent fatigue in breast cancer survivors. Clin Cancer Res. 2006;12:2759-66.

10. Rich T, Innominato PF, Boerner J, dkk. Elevated serum cytokines correlated with altered behavior, serum cortisol rhythm, and dampened 24-hour rest-activity patterns in patients with metastatic 
colorectal cancer. Clin Cancer Res. 14. Mock V, Pickett M, Ropka ME, dkk. 2005;11:1757-64. Fatigue and Quality of Life Outcomes of

11. Cang PH, Lai YH, Shun SC, dkk. Effect Exercise During Cancer Treatment. of a walking intervention on fatiguerelated experience of hospitalized acute myelogenous leukemia patients undergoing chemotherapy: A randomized controlled trial. J Pain Symptom Manage. 2008;35:524-34.

Cancer Pract. 2001;9:119-27.

15. Husebø AML, Dyrstad SM, Mjaaland I, dkk. Clinical Study Effects of Scheduled Exercise on Cancer-Related Fatigue in Women with Early Breast Cancer. The Scientific World Journal. 2014;2014:271828.

12. Milne HM, Wallman KE, Gordon S, dkk. 16. Velthuis MJ, Agasi-Idenburg SC, Effects of a combined aerobic and resistance exercise program in breast cancer survivors: a randomized controlled trial. Breast Cancer Res Treat. 2008;108:279-88.

13. Wahyuni IS, Sudiana IK, Mariyanti H. Walking Exercise Programme (WEP) Menurunkan Cancer Related Fatigue (CRF) Pada Pasien Kanker Payudara Di RSUD Ibnu Sina Gresik. Critical Medical and Surgical Nursing Journal. 2012;1: 28-37. Aufdemkampe G, dkk. The Effect of Physical Exercise on Cancer-related Fatigue during Cancer Treatment: a Metaanalysis of Randomised Controlled Trials. Clin Oncol (R Coll Radiol). 2010;22:20821.

17. Alghadir AH, Gabr SA, Aly FA. The Effects of Four Weeks Aerobic Training on Saliva Cortisol and Testosterone in Young Healthy Persons. J Phys Ther Sci. 2015;27:2029-33. 